\title{
Genetic diversity of a natural population of Mezilaurus itauba (Meisn.) Taub. ex Mez. in the southern Amazon, Brazil
}

\section{Diversidade genética em população natural de Mezilaurus itauba (Meisn.) Taub. ex Mez. no sul da Amazônia, Brasil}

\author{
Alexandre Ebert ${ }^{1}$; Aisy Botega Baldoni Tardin²; \\ Leandro Skowronski ${ }^{3}$; Michel Constantino ${ }^{4}$; \\ João Henrique de Souza Barros ${ }^{3}$; Reginaldo Brito da Costa ${ }^{4 *}$
}

\begin{abstract}
Genetic diversity studies in natural forest species populations have consistently expanded in recent years. Considering that biodiversity is directly related to genetic variation among and within populations, its study has become essential to the knowledge of genetic patterns. The study assessed genetic diversity of a Mezilaurus itauba population, detecting similarity and dissimilarity evaluating distribution intensity of adult and juvenile trees in remnant rain forest fragments in southern Amazon, Brazil. Leaf and cambium samples were randomly collected from 36 reproductive individuals. Eleven RAPD (randomamplified polymorphic DNA) primers were tested for genetic similarity analyses. The obtained data demonstrated that the species presented $79.77 \%$ polymorphism among the loci observed, with genetic diversity occurring between juvenile and adult trees. The population studied presented genetic diversity, forming three well-distinguished groups.
\end{abstract}

Key words: Conservation. Forest management. Genetic population. Genetic similarity.

\section{Resumo}

Estudos de diversidade genética em populações de espécies florestais naturais têm expandido consistentemente nos últimos anos. Considerando que a biodiversidade está diretamente relacionada à variação genética entre e dentro das populações, o seu estudo tornou-se essencial para o conhecimento dos padrões genéticos. O estudo avaliou a diversidade genética de uma população de Mezilaurus itauba, detectando similaridade e dissimilaridade em fragmentos de floresta tropical remanescente no sul da Amazônia, Brasil. Amostras de folhas e do câmbio foram coletadas aleatoriamente a partir de 36 indivíduos reprodutivos. Onze RAPD (DNA polimórfico aleatoriamente amplificado) iniciadores foram testados para a análise de similaridade genética. Os dados obtidos demonstraram que a espécie apresentou $79,77 \%$ de polimorfismo entre os loci observados, com diversidade genética que ocorre entre indivíduos arbóreos juvenis e adultos. A população estudada apresentou diversidade genética, formando três grupos bem distintos.

Palavras-chave: Conservação. Manejo florestal. Genética de população. Similaridade genética.

\footnotetext{
${ }^{1}$ Discente de Doutorado em Economia, Universidade Federal de Mato Grosso, UFMT, Cuiabá, UF, Brasil. E-mail: ebertfloresta@ yahoo.com.br

2 Pesquisadora Dr ${ }^{\mathrm{a}}$, Embrapa Agrossilvipastoril, Sinop, MT, Brasil. E-mail: aisy.baldoni@embrapa.br

${ }^{3}$ Discente de Doutorado em Ciências Ambientais e Sustentabilidade Agropecuária, Universidade Católica Dom Bosco, UCDB, Campo Grande, MS, Brasil. E-mail: 1sk@ucdb.br; barros.jhs@gmail.com

4 Profs. Drs., Programa em Ciências Ambientais e Sustentabilidade Agropecuária, UCDB, Campo Grande, MS, Brasil. E-mail: michel@ucdb.br; reg.brito.costa@gmail.com

* Author for correspondence
} 


\section{Introduction}

Vegetation is a major bioindicator in ecological studies of biodiversity in forest systems. A wellknown approach to studying plant diversity is to identify the genetic differentiation among and within populations (COSTA et al., 2015; FERREIRA; GRATTAPAGLIA, 1998). Pires et al. (2011) emphasized the importance of genetic resource conservation programs in economically explored forest communities to avoid the collapse of target forest species. Genetic equilibrium is naturally manifested in large populations in the absence of migration, mutation and selection with allelic and genotypic frequencies remaining constant across several generations according to the Hardy-Weinberg 's theorem.

Mezilaurs itauba (Meins.) Taub. Ex Mez is an Amazon species distributed throughout South America, from the southern Amazon and northern Brazil to Colombia, Venezuela, Guyana, French Guiana and Ecuador. It is the fifth most exploited timber species in the region, due the excellent technical characteristics of the wood, and it is listed as threatened for extinction in the Amazon region by the International Union for Nature Conservation (IUCN, 2009). The spatial pattern of the population of Mezilaurus itauba in the southern Amazon was random, though a tendency to aggregation at very close distances was detected (EBERT et al., 2016).

Genetic diversity refers to the variation of genes within and between species and their structure, corresponding to the diversity of genotypes and their abundance or variation within populations. High genetic diversity in a population is especially valuable when the environment is unstable and unpredictable because it improves adaptation to natural or anthropic interventions through genotype selection (BERG, 2001).

The standards established by current Brazilian legislation concerning timber harvest in the Amazon rain forest, which basically apply dendrometric patterns, may lead to irreparable ecological and genetic losses to the structural dynamic ofAmazonian forests. An approach is receiving attention from the contemporary scientific community is population monitoring of the structure and genetic diversity of explored timber tree species, which seeks to establish genetic indicators that contribute to biodiversity conservation initiatives (BOYLE, 2000). However, Kageyama et al. (2003) described the difficulty in including a large number of species in genetic diversity studies due to the wide range of natural tropical forest species, and they suggested the assessment of selected species, which would serve as representatives for a common group due to their ecological and genetic characteristics.

The study assessed genetic diversity of a Mezilaurus itauba population, evaluating distribution of adult and juvenile trees in remnant rain forest fragments in southern Amazon, Brazil.

The sampling area, covering 185 hectares, was located in a semi-decidual forest in the Sorriso Municipality of the Northern Mato Grosso State,

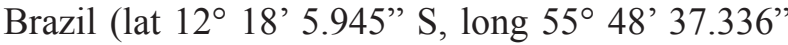
W). From a population of 156 trees, samples were collected from 36 individuals through simple random sampling, providing $86 \%$ confidence interval. Fresh samples of leaves and cambium were collected from individual Mezilaurus itauba specimens. Leaves were stored in identified plastic bags and transported in styrofoam boxes containing ice. Cambium samples were extracted and added to individual 50 $\mathrm{mL}$ tubes along with a transport solution containing ascorbic acid, cetyltrimethylammonium bromide (CTAB), $\beta$-mercaptoethanol and absolute ethanol.

Exsiccates samples were used in species identification and were deposited in the Central Herbarium of the Federal University of Mato Grosso, Brazil.

Groups with samples distributed to maintain proportionality in the number of individuals with physiological or ontogenetic characteristics at the reproductive stage. Trees harvested for timber usually have a diameter at breast height $(\mathrm{DBH})$ 
greater than $50 \mathrm{~cm}$, and this parameter was used for classifying adult and juvenile populations.

Samples were collected from a total of 36 individuals as follows: 20 individuals with a $\mathrm{DBH}$ equal or greater than $50 \mathrm{~cm}$, and 16 individuals with a DBH less than $49.9 \mathrm{~cm}$. A DNA extraction protocol was performed as described by Ferreira and Grattapaglia (1998). Briefly, plant tissue was macerated, extracted using buffer solution and stored in microtubes. DNA samples were quantified by concentration and purity readings using a NanoDrop ${ }^{\circledR}$ spectrophotometer. Following quantification, the samples were diluted in ultrapure water (milli-Q) to a concentration of $4.2 \mathrm{ng} \mu \mathrm{L}^{-1}$. DNA samples were frozen at a constant temperature of $-20^{\circ} \mathrm{C}$. The polymerase chain reaction (PCR) protocol consisted of denaturation of doublestranded DNA for amplification, and the temperature indicated for tropical tree species was used $\left(92^{\circ} \mathrm{C}\right.$ for 1 minute). The annealing temperature was $38^{\circ} \mathrm{C}$ for 2 minutes in 35 repeated cycles.

Eleven random amplified polymorphic DNA (RAPD) primers (Table 1), from commercial laboratories for the same family as the species studied, were used.

Table 1. Primers utilized in the RAPD PCR, total number of bands, total number of polymorphic bands and the percentage of polymorphism.

\begin{tabular}{lccccc}
\hline \multirow{2}{*}{$N^{\circ}$ Name of oligonucleotide } & Sequence & \multicolumn{3}{c}{ Number of bands } \\
\cline { 4 - 6 } & P4 & Total & Polymorphic & \% \\
\hline 1 & P6 & '5-AAGTCCGCTC-3' & 10 & 8 & 8.99 \\
3 & P10 & '5-CCACGGGAAG-3' & 12 & 9 & 10.11 \\
4 & P16 & '5-TCAGAGCGCC-3' & 3 & 3 & 3.37 \\
5 & P19 & '5-AAGACCCCTG-3' & 12 & 10 & 11.24 \\
6 & P40 & '5-CTTCACCCGA-3' & 8 & 5 & 5.62 \\
7 & P48 & '5-AGCGCCATTG-3' & 11 & 9 & 10.11 \\
8 & P50 & '5-GGCACGCGTT-3' & 10 & 9 & 10.11 \\
9 & P51 & '5-ACGGCGTATG-3' & 1 & 1 & 1.12 \\
10 & P52 & '5-CATCCGTGCT-3' & 8 & 6 & 6.74 \\
11 & P53 & '5-AATCGGGCTG-3' & 11 & 9 & 10.11 \\
\hline
\end{tabular}

For image analysis, Image LAB 4.0 software (Bio-Rad Laboratories, Inc.) was used for capturing open band classification during the electrophoretic runs and documentation of the photographs. Gels were analyzed by constructing binary matrices to determine the presence of bands (1) and the absence of bands (0). The distribution of genetic diversity was evaluated by grouping analysis using the spatial distribution of two individuals [Group 1, adult trees ( $\geq 50 \mathrm{~cm} \mathrm{DBH})$; and Group 2, juvenile trees $(<$ $50 \mathrm{~cm} \mathrm{DBH})]$. Genetic dissimilarity between the individuals was determined by grouping analysis of the betweenness of each pair of observations, as follows (HAIR et al. 2005): , where $S_{j i}$ represents the genetic similarity, $a$ represents the presence of banding in the genotypes, $b$ represents the presence of banding in the first genotype and the absence of banding in the second genotype, and $c$ represents the absence of banding in the first genotype and the presence of banding in the second genotype.

The construction of a dendrogram of hierarchical clustering from complete linkage was the grouping technique adopted for the analyses of genetic dissimilarity, and this technique grouped the samples by mean distance between the object, aiming for inclusion in a group and for each object to pertain to that group. 
Through the binary matrix generated by the interpretation of the bands, the percentage of polymorphism in each oligonucleotide was determined using the following formula: , where $P$ is the percentage of polymorphism, $n p b$ is the number of polymorphic fragments, and $n b t$ is the number of total fragments.

Polymorphism detection showed 89 bands containing 71 polymorphic bands (79.77\%). The P6 and $\mathrm{P} 16$ primers corresponded to high polymorphism with 12 alleles identified for each primer, and the P50 primer presented low polymorphism with only 1 allele identified (Table 1), proved effective for the characterization and evaluation of $M$. itauba genetic diversity with RAPD markers. The main advantages found compared to other types of markers, as reported by several researchers, were confirmed to be low costs, reduced lab analysis execution time and the small amounts of plant material required.

Both collection methods (young leaves and cambium) were shown to be effective because DNA samples were successfully obtained from both. However, the cambium samples stored in transport buffer solution were better, due to the simplicity and ease of field collection and the fewer labor requirements for preparation of DNA in the lab. From the 36 samples collected, 29 samples were successfully extracted $(80.55 \%$ success rate) to obtain good quality material and amounts sufficient for genetic analyses.

These results suggest that the elevated rate of intrapopulational polymorphisms indicates high genetic variability and diversity, despite the anthropic. A reduction of genetic diversity in populations, which is often caused by human actions, directly affects the evolutionary capacity of the species. The effective population size is reduced, thus making the population less able to adapt to environmental changes because they become an endogamous population via inbreeding, resulting in a loss of heterozygosity (FRANKHAN et al., 2002). Gomes et al. (2011) evaluated the genetic diversity of Mauritia flexuosa L. f. (Areaceae) using amplified fragment length polymorphism (AFLP) markers in four populations, and they obtained mean polymorphism percentages between 82 and 91.1\%. Kageyama et al. (2003) utilized RAPD molecular markers in a genetic diversity study of an Ocotea odorifera (Lauraceae) population, and they verified $95 \%$ polymorphic loci. Sandigawab and Patil (2011) found 89\% polymorphism using 11 RAPD primers in Cinnamomum zeylanicum Blume (Lauraceae).

In the present study, the polymorphic loci analysis of the two groups yielded $47.42 \%$ polymorphism for the juvenile tree alleles and $53.58 \%$ polymorphism for the adult tree alleles. These results suggested that genetic diversity can be maintained if timber harvest is based on strict forest management regimes that remove individuals only from the adult tree group (>50 cm DBH). Accordingly, as it was highlighted that important alleles can be lost during exploitation, some loci were found only in the adult species group.

Agenotype distribution equilibrium was observed between the two groups, thus allowing genetic diversity to be maintained across the generations of existing trees in the population studied. This equilibrium may be related to the alogamous reproduction system, pollination syndromes and seed dispersion, which maintain the natural genetic structure of forest through stimulating genetic exchanges given the current density and frequency of individuals in the population.

The genetic dissimilarity dendrogram generated by the complete hierarchical clustering method illustrates the results (Figure 1). The cutoff line for similarity was drawn at a mean dissimilarity of $55 \%$, and three groups were formed. The further 13 samples showed similarity under cutoff line, indicating genetic diversity among themselves and with the three distinct groups.

The first group encompassed samples 1, 2, 7, $8,11,12,13,14$ and 18. Samples 1, 2, 8, 11, 12 
and 13 were from the adult individuals, and 7, 14 and 18 were from the juvenile individuals. For the second group, samples 3 and 4 were from the juvenile group, and 6 and 9 were from the adult group. For the third group, sample 15 was from the adult group, and 16 and 17 were from the juvenile group. Genetic diversity was maintained within the population studied as a function of historical events that had occurred and other more recent evolutionary processes (LEE et al., 2002). Few studies related to the $M$. itauba species with the data obtained relating to the technology employed in timber production have been performed.
The dendrogram revealed that the levels of genetic diversity varied among samples, which allowed the organization of the genetic variability in the population to be known. This knowledge is useful for genetic diversity conservation, and it allows exploration of the evolutionary potential of the species (HAMRICK; GODT, 1997). It is important to analyze the genetic dissimilarity among individuals within groups because it reflects the differences in the phenotypic standards observed using genetic analysis.

Figure 1. Grouping of individuals from the Mezilaurus itauba (Meinz.) Taub. Ex Mez population studied using the similarity index in the grouping method. The cutoff line was estimated and shown to be at a $55 \%$ similarity.

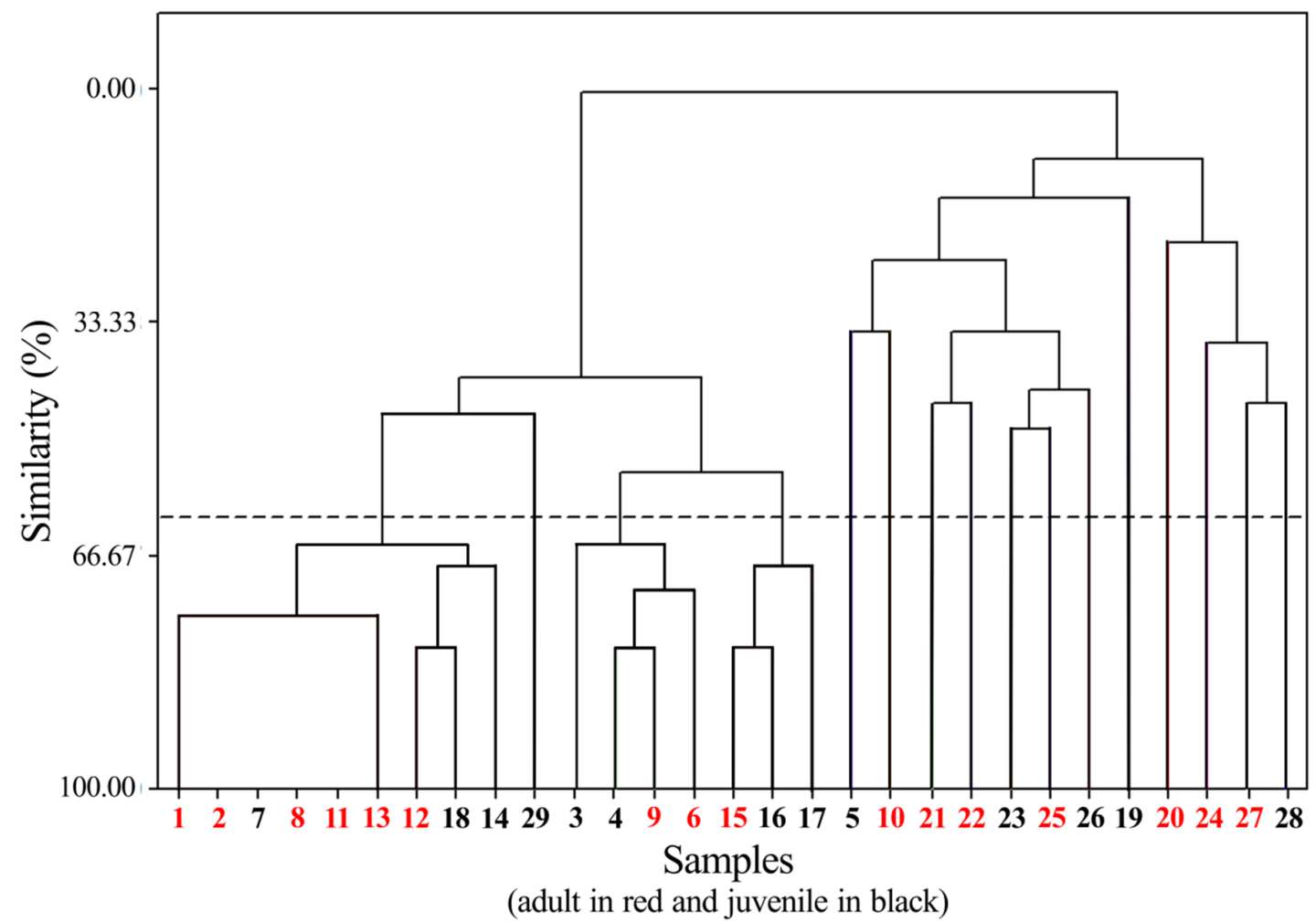

The population studied presented genetic diversity, having three distinct groups and the further 13 samples showed similarity under cutoff line, indicating genetic diversity among themselves and with the three distinct groups. The levels of genetic diversity varied among samples, which allowed the organization of the genetic variability in the population. The primers used were effective in identifying genetic variability of $M$. itauba and can be used in study of forest management to the specie. 


\section{Acknowledgments}

The authors thank the Coordenação de Aperfeiçoamento de Pessoal de Ensino Superior (CAPES) and Conselho Nacional de Desenvolvimento Científico e Tecnológico (CNPq) for the support to this work through fellowships to the authors.

\section{References}

BERG, E. V. D. Estrutura e ecologia de comunidades e populações vegetais. Curso de Pós-Graduação: gestão e manejo ambiental em sistemas florestais. Lavras: UFLA/ FAEPE, 2001. 29 p.

BOYLE, T. J. Criteria and indicators for the conservation of genetic diversity. In: YOUNG, A.; BOSCHIER, D.; BOYLE, T. J. (Ed.). Forest conservation genetics: principles and practice. CSIRO Publishing: Collingwood, 2000. p. 259-252.

COSTA, L. S.; CORNELEO, N. S.; STEFENON, W. M. Conservation of forest biodiversity: how sample size affects the estimation of genetic parameters. Anais da Academia Brasileira de Ciências, Rio de Janeiro, v. 87, n. 2, p. 1095-1100, 2015.

EBERT, A.; COSTA, R. B.; BRONDANI, G. E. Spatial distribution pattern of Mezilaurus itauba (Meins.) Taub. Ex mez. in a seasonal forest area of the southern Amazon, Brazil. iForest-Biogeosciences and Forestry, Viterbo, v. 9, n. 3, p. 497-502, 2016.

FERREIRA, M. E.; GRATTAPAGLIA, D. Introdução ao uso de marcadores moleculares em análise genética. 2. ed. Brasília: EMBRAPA/CENARGEN, 1998. 220 p.

FRANKHAN, R.; BALLOU, J. D.; BRISCOE, D. A. Introduction to conservation genetics. Cambridge: Cambrige University Press, 2002. 617 p.
GOMES, L. R. P.; LOPES, M. T. G.; BENTES, J. L. S.; BARROS, W. S.; COSTA NETO, P. Q.; CONTIM, L. A. S. Genetic diversity in natural populations of Buriti (Mauritia flexuosa L. f.). Crop Breeding and Applied Biotechnology, Viçosa, v. 11, n. 3, p. 216-223, 2011.

HAIR, J. F.; ANDERSON, R. E.; TATHAM, R. L.; BLACK, W. C. Análise multivariada de dados. 5. ed. Porto Alegre: Bookman, 2005. 593 p.

HAMRICK, J. L.; GODT, M. J. W. Effects of life history traits on genetic diversity in plant species. In: SILVERTOWN, J.; FRANCO, M.; HARPER, J. L. (Ed.). Plant life histories. Ecology, phylogeny and evolution. Cambridge University Press, Cambridge, 1997. p. 102118.

UNIÃO INTERNACIONAL PARA CONSERVAÇÃO DA NATUREZA - IUCN. IUCN red list of threatened species (version 2009.2). International Union for Conservation of Nature, Web Site. Disponível em: $<$ http://www.iucnredlist.org >. Acesso em: 11 mar. 2016.

KAGEYAMA, P. Y.; SEBBEN, A. M.; RIBAS, L. A.; GANDARA, F. B.; CASTELLEN, M.; PERECIN, M. B.; VENCOVSKY, R. Diversidade genética em espécies arbóreas tropicais de diferentes estágios sucessionais por marcadores genéticos. Scientia Forestalis, Piracicaba, n. 64, p. 93-107, 2003.

LEE, S. L.; NG, K. K. S.; SAW, L. G.; NORWATI, A.; SALWANA, M. H. S.; LEE, C. T.; NORWATI, M. Population genetics of Intsia palembanica (Leguminosae) and genetic conservation of Virgin Jungle Reserves in Peninsular Malaysia. American Journal of Botany, St. Louis, v. 89, n. 3, p. 447-459, 2002.

PIRES, I. E.; RESENDE, M. D. V.; SILVA, R. L.; RESENDE JUNIOR, M. F. R. Genética florestal. Viçosa: UFV, $2011.318 \mathrm{p}$.

SANDIGAWAB, A. M.; PATIL, C. G. Genetic diversity in Cinnamomum zeylanicum Blume. (Lauraceae) using random amplified polymorphic DNA (RAPD) markers. African Journal of Biotechnology, Nairobi, v. 10, n. 19, p. 3682-3688, 2011. 